\title{
Pendampingan Manajemen Pengelolaan Keuangan \\ Pada Kelompok Usaha "Wanita Mandiri" \\ Di Kelurahan Jogotrunan \\ Kabupaten Lumajang
}

Ainun Jariah

Program Studi Manajemen, STIE Widya Gama Lumajang

anjar040820@gmail.com

\begin{abstract}
Abstrak
Kegiatan ini bertujuan untuk mendampingi kelompok usaha "Wanita Mandiri" Kelurahan Jogotrunan Kecamatan Lumajang Kabupaten Lumajang sehingga mereka mampu mengelola manajemen usahanya, melaksanakan pembukuan usaha secara teratur, dan mampu memisahkan keuangan rumah tangga dengan keuangan usaha, serta memiliki strategi pemasaran yang memberikan keuntungan lebih dan mampu bersaing dengan usaha lainnya dan pemberian bantuan dana untuk tambahan modal usaha. Adapun metode kegiatan pengabdian masyarakat ini memiliki beberapa tahapan, antara survey awal, wawancara pada kelompok mitra guna menemukan permasalahan dan solusi yang ditawarkan serta pendampingan manajemen terutama manajemen keuangan. Kelompok usaha "Wanita Mandiri" ini meliputi beberapa jenis usaha yang dijalani antara lain: (1) usaha kebun dan dagang bunga anggrek; (2) dagang kebutuhan primer sekunder melalui pemasaran on line; (3) warung / kedai makanan gado-gado; (4) penjahit; (5) usaha salon kecantikan; (6) usaha penjualan bibit lele; (7) usaha penjualan hasil kebun. Kelompok usaha "Wanita Mandiri" ini berawal dari beberapa ibu yang memiliki masing-masing usaha dan setuju membentuk kelompok untuk sekedar curhat dan berbagi ilmu dalam rangka meningkatkan keuntungan usahanya. Peningkatan kemampuan mengelola keuangan secara benar dan teratur, serta mampu memisahkan antara keuangan rumah tangga dengan keuangan usaha, penguatan strategi pemasaran agar mampu bersaing dalam memasarkan produknya.
\end{abstract}

\section{Kata Kunci: Kelompok usaha "Wanita Mandiri", Manajemen keuangan, Strategi} pemasaran.

\section{Abstract}

This activity aims to assist the "Mandiri Women" business group in the Jogotrunan SubDistrict Lumajang District, Lumajang Regency so that they are able to manage their business management, carry out business bookkeeping regularly, and are able to separate household finances from business finance, and have marketing strategies that provide more benefits and compete with other businesses and provide financial assistance for additional business capital. The method of community service activities has several stages, between initial surveys, interviews with partner groups to find problems and solutions offered and management assistance, especially financial management. This "Mandiri Women" business group covers several types of businesses that are undertaken, among others: (1) orchid flower trading and trading business; (2) trading secondary primary needs through online marketing; (3) gadogado food stalls / shops; (4) tailor; (5) beauty salon business; (6) efforts to sell catfish seeds; (7) business of selling garden produce. This "Mandiri Women" business group originated from several mothers who had each business and agreed to form groups to just vent and share 
knowledge in order to increase the profits of their business. Increased ability to manage finances properly and regularly, and be able to separate household finances from business finance, strengthening marketing strategies to be able to compete in marketing their products.

\section{Keywords: "Mandiri Women" business group, financial management, marketing strategy.}

\section{PENDAHULUAN}

Wanita dengan kodratnya seakan ditakdirkan untuk berada didalam rumah dan untuk memenuhi kebutuhan ekonominya merupakan tanggung jawab suaminya. Tetapi saat ini jaman semakin bergeser dan berkembang bahwa untuk memunuhi kebutuhan rumah tangga, peran seorang wanita atau istri juga harus bisa memberikan tambahan penghasilan bagi keluarganya. Jaman nampaknya bergerak ke arah emansipasi wanita dimana saat ini banyak kita temukan para istri atau wanita yang bekerja baik mandiri maupun berdampingan dengan suaminya.

Keberadaan wanita dalam ekonomi rumah tangga saat ini nampaknya tidak bisa dianggap remeh karena justru dari tangan-tangan kreatif wanita inilah, banyak perekonomian rumah tangga yang sangat terbantu dan justru semakin mapan. Namun demikian akan sangat bijaksana apabila seorang wanita atau istri memilih usaha yang tidak meninggalkan kodratnya sebagai seorang istri yang harus tetap menganggap bahwa keluarga adalah nomor satu. Kewajiban mendidik dan mendampingi keluarga tetap harus menjadi prioritas utama.

Berangkat dari alasan inilah maka muncul ketertarikan untuk bermitra dengan kelompok usaha "Wanita Mandiri" di Kelurahan Jogotrunan Kabupaten Lumajang. Kelompok usaha "Wanita Mandiri" merupakan kelompok usaha yang terdiri dari berbagai macam usaha dari sekelompok ibu rumah tangga di Kelurahan Jogotrunan Kecamatan Lumajang Kabupaten Lumajang. Mereka masing-masing mendirikan usaha dan saling berkomunikasi dalam menjalankan usahanya yang memang tujuan utamanya adalah untuk membantu perekonomian keluarganya masing-masing. Usaha-usaha yang mereka tekuni tidak lantas meninggalkan kewajiban mereka sebagai ibu rumah tangga. Namun demikian sampai saat ini kelompok usaha ini hanya menjalankan usahanya seadanya saja dan sangat sederhana tetapi mereka tetap memiliki keinginan yang kuat untuk maju. Seringkali usaha mereka kalah dalam bersaing dengan usaha lainnya.

Kelompok sasaran dalam kegiatan ini adalah kelompok usaha yang terdiri dari beberapa usaha kecil yang dijalankan oleh sekelompok wanita di Kelurahan Jogotrunan Kecamatan Lumajang Kabupaten Lumajang yang menamakan dirinya kelompok usaha "Wanita Mandiri". Para ibu rumah tangga yang tergabung dalam kelompok usaha ini masih memiliki beberapa keterbatasan antara lain kurangnya kemampuan dalam mengelola manajemen usahanya, belum adanya pencatatan atau pembukuan usaha secara teratur, belum adanya pemisahan yang jelas antara keuangan rumah tangga dengan keuangan usaha, dan lemahnya strategi pemasaran yang digunakan sehingga keuntungan yang diperoleh sedikit, usaha kurang berkembang dengan baik karena cenderung kalah dalam persaingan.

Tetapi para ibu ingin mengembangkan usahanya, mengelola keuangan usahanya dengan benar dan mampu menghadapi persaingan dalam memasarkan produknya. Semangat untuk maju dan berkembang inilah yang menjadi dasar pertimbangan diselenggarakannya kegiatan pengabdian kepada masyarakat dalam bentuk pendampingan manajemen pengelolaan keuangan sederhana dan manajemen pemasaran yang efektif untuk meningkatkan usaha mereka agar berkembang lebih baik. 
Berdasarkan survey awal dan analisis situasi yang telah dilakukan, kelompok ini mempunyai permasalahan sebagai berikut :

1. Terbatasnya kemampuan sumber daya manusia dalam mengelola manajemen usahanya.

2. Belum adanya pencatatan atau pembukuan usaha secara teratur.

3. Belum adanya pemisahan yang jelas antara keuangan rumah tangga dengan keuangan usaha.

4. Lemahnya strategi pemasaran yang digunakan sehingga berakibat keuntungan yang diperoleh sedikit, usaha kurang berkembang dengan baik karena cenderung kalah dalam persaingan.

Selanjutnya pembicaraan formal dengan kelompok mitra ini menghasilkan kesepakatan bahwa mitra menginginkan bisa mengembangkan usahanya, mengelola keuangan usahanya dengan benar dan mampu menghadapi persaingan dalam memasarkan produknya.

Solusi yang ditawarkan dalam kegiatan pengabdian kepada masyarakat pada kelompok usaha "Wanita Mandiri" ini sebagai berikut :

1. Meningkatkan kemampuan mengelola keuangan secara benar dan teratur, serta mampu memisahkan antara keuangan rumah tangga dengan keuangan usaha.

2. Memperkuat strategi pemasaran kelompok wirausaha agar mampu bersaing dalam memasarkan produknya.

3. Pemberian bantuan dana untuk tambahan modal usaha mitra.

Kegiatan pengabdian kepada masyarakat ini diharapkan dapat menghasilkan target sesuai dengan harapan kelompok mitra, sebagai berikut:

1. Peningkatan ketrampilan mitra dalam menjalankan usahanya dengan berkelanjutan.

2. Peningkatan kemampuan administrasi sederhana yang tertib dan sehat, dalam arti mampu memisahkan keuangan rumah tangga dengan keuangan usaha.

3. Peningkatan omzet penjualan dari kegiatan pemasaran yang efektif.

4. Dana untuk tambahan modal usaha.

Kegiatan pengabdian kepada masyarakat yang melibatkan Dosen ini diharapkan dapat menjadi ajang bagi Dosen dalam melaksanakan salah satu Tri Dharma Perguruan Tinggi yaitu dibidang pengabdian kepada masyarakat serta menerapkan ilmu yang dimiliki untuk berbagi dengan masyarakat di realitanya.

\section{METODE PELAKSANAAN}

Adapun metode pelaksanaan kegiatan dilakukan melalui tahapan sebagai berikut:

a. Metode Wawancara

Metode wawancara, adapun materi wawancara meliputi: identitas kegiatan, modal, jumlah anggota, macam usaha, permasalahan-permasalahan mitra.

b. Metode Pendampingan

Metode ini dilakukan dengan cara pendampingan dan pemberian wawasan mengenai peningkatan kemampuan dalam mengelola keuangan secara benar dan teratur, peningkatan kemampuan dalam memisahkan antara keuangan rumah tangga dengan keuangan usaha, peningkatan kemampuan dalam memperkuat strategi pemasaran kelompok wirausaha agar mampu bersaing dalam memasarkan produknya.

c. Metode Pemberian Bantuan Dana

Bantuan diberikan kepada kelompok usaha "Wanita Mandir" Kelurahan Jogotrunan Kecamatan Lumajang Kabupaten Lumajang berupa dana untuk menunjang biaya operasional senilai Rp 2.000.000,-. 


\section{HASIL DAN PEMBAHASAN}

Kelompok usaha "Wanita Mandiri" merupakan kelompok usaha yang terdiri dari berbagai macam usaha dari sekelompok ibu rumah tangga di Kelurahan Jogotrunan Kecamatan Lumajang Kabupaten Lumajang. Mereka masing-masing mendirikan usaha dan saling berkomunikasi dalam menjalankan usahanya yang memang tujuan utamanya adalah untuk membantu perekonomian keluarganya masing-masing. Adapun beberapa jenis usaha yang dijalani sebagai berikut :

1. Usaha kebun dan dagang bunga anggrek

2. Dagang kebutuhan primer sekunder melalui pemasaran online

3. Warung / kedai makanan Gado - Gado

4. Penjahit

5. Usaha salon kecantikan

6. Usaha penjualan bibit lele

7. Usaha penjualan hasil kebun

Kelompok usaha "Wanita Mandiri" rutin melakukan pertemuan setiap minggu untuk membahas beberapa permasalahan yang mereka hadapi, temukan, dan mencari solusi terbaik untuk setiap masalah dalam usaha yang mereka jalani.

\section{Kunjungan Ke Tempat Usaha Mitra}
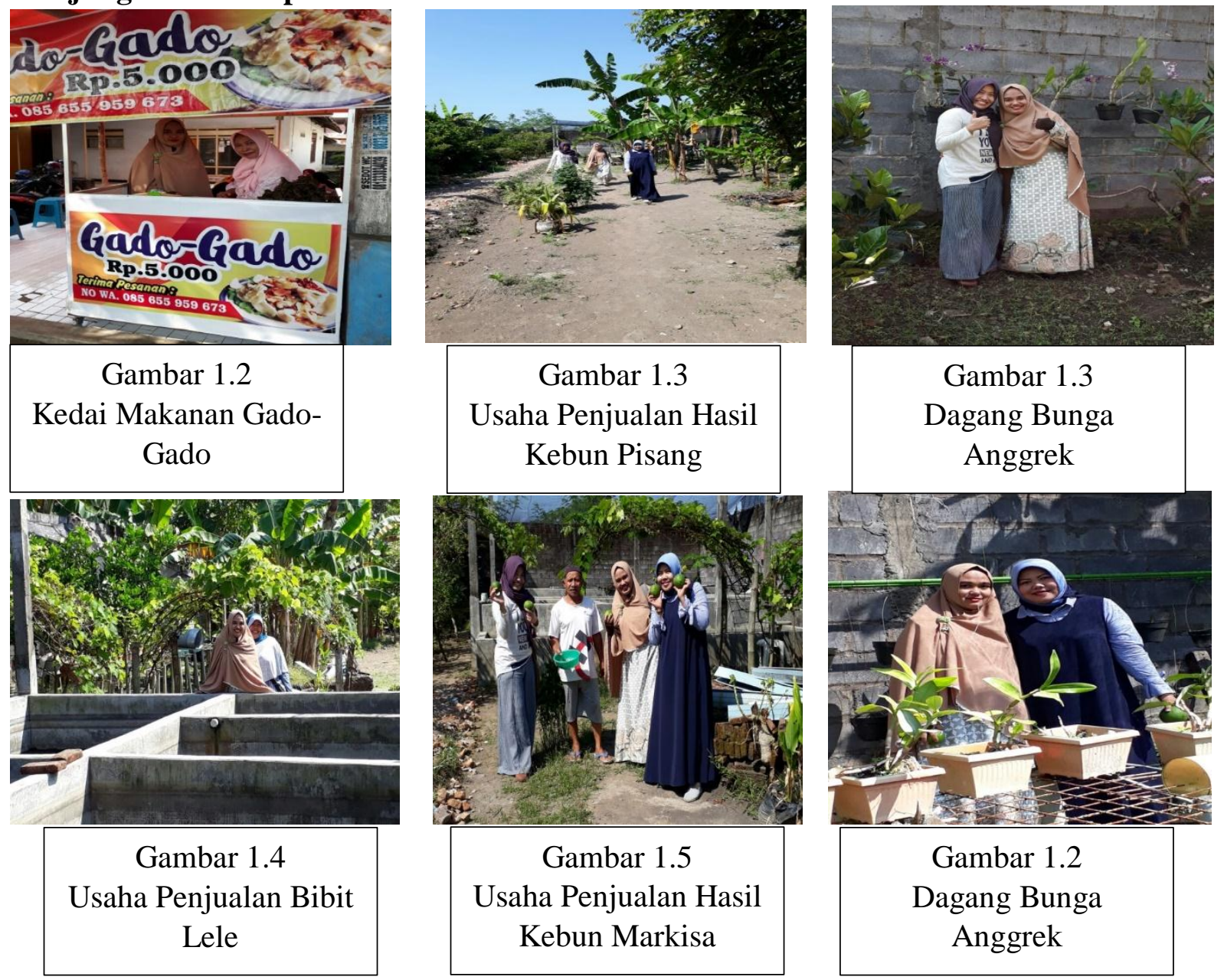

Adapun permasalahan-permasalahan mitra antara lain:

1. Terbatasnya kemampuan dalam mengelola manajemen usahanya.

2. Belum adanya pencatatan atau pembukuan usaha secara teratur. 
3. Belum adanya pemisahan yang jelas antara keuangan rumah tangga dengan keuangan usaha.

4. Lemahnya strategi pemasaran yang digunakan.

Semangat mitra dalam mengembangkan kelompok usahanya layak untuk mendapat apresiasi kita sebagai dosen. Pada tanggal 30 sampai dengan 31 Maret 2018 melakukan pendampingan manajemen usaha, manajemen keuangan, pencatatan atau pembukuan usaha secara teratur, dan penguatan strategi pemasaran.

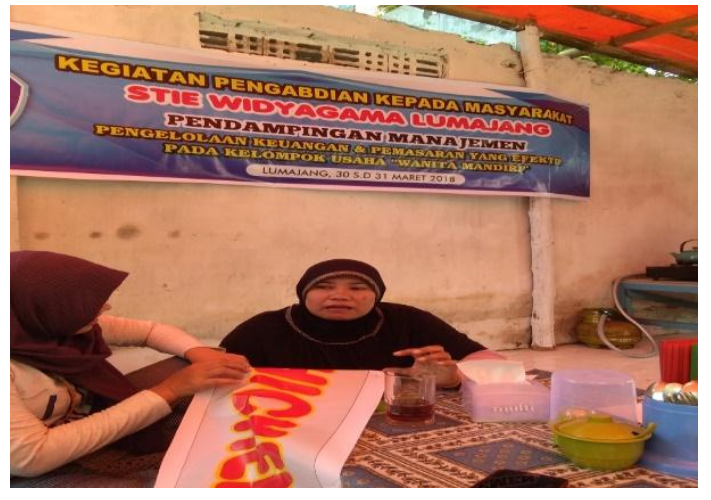

Gambar 2.1

Pendampingan Manajemen Usaha

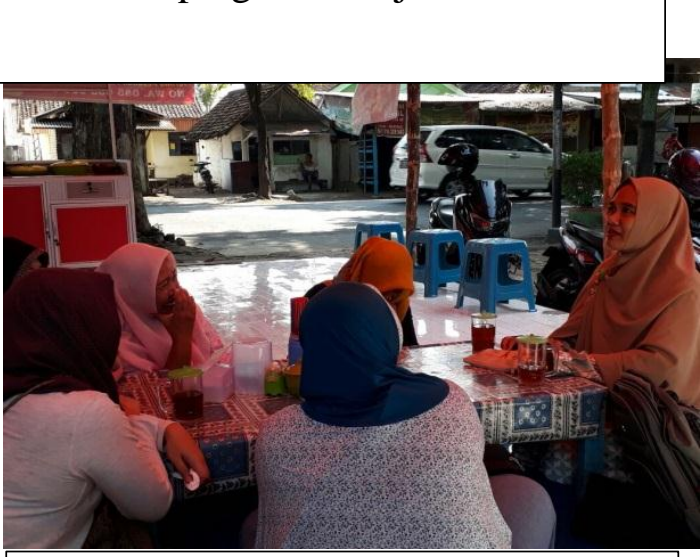

Gambar 2.3

Pendampingan Pembukuan secara Teratur dan Benar

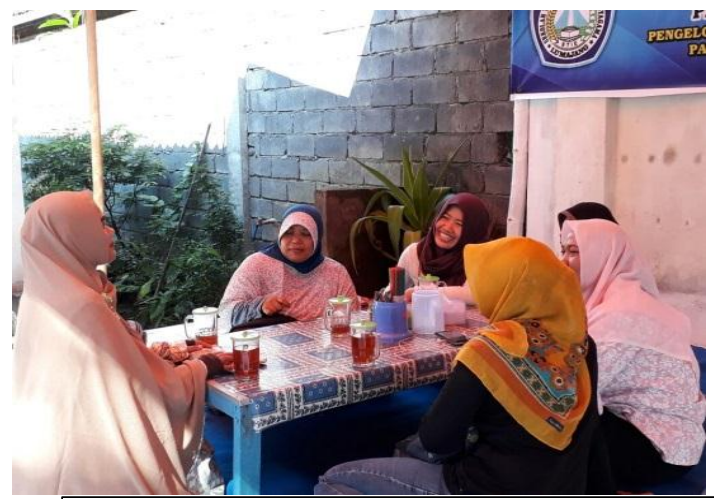

Gambar 2.2

Pendampingan Manajemen Keuangan

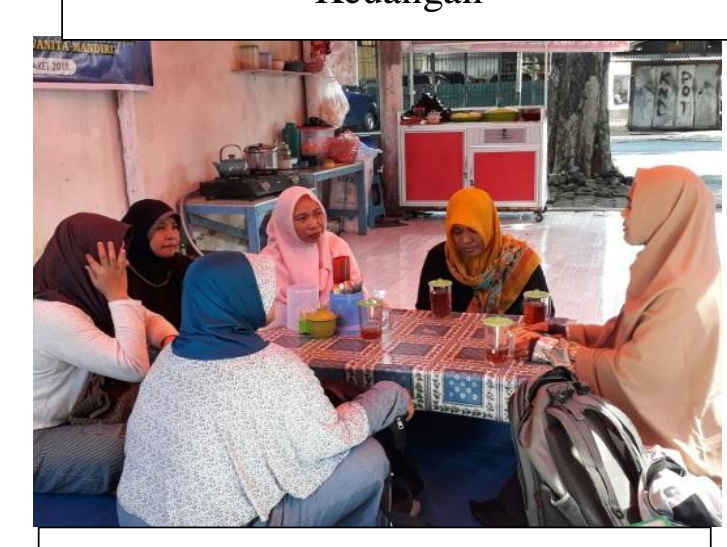

Gambar 2.4

Pendampingan Penguatan Strategi

Pemasaran

Bantuan dana sebesar Rp 2.000.000,- diberikan kepada Kelompok Usaha "Wanita Mandiri" Kelurahan Jogotrunan Kecamatan Lumajang Kabupaten Lumajang guna membantu menunjang anggaran biaya operasional dan penambahan modal untuk para anggotanya.

\section{KESIMPULAN}

Beberapa hal yang dapat disimpulkan dalam pelaksanaan pendampingan manajemen pada kelompok usaha "Wanita Mandiri" di Kelurahan Jogotrunan Kecamatan Lumajang Kabupaten Lumajang ini sebagai berikut:

a. Mitra usaha "Wanita Mandiri" memiliki keinginan yang kuat untuk mengembangkan usahanya mengingat persaingan usaha sejenis yang cukup tajam di Lumajang. Keterbatasan dalam mengelola keuangan dan memasarkan produknya dengan efektif, menjadi permasalahan bagi mitra yang membutuhkan solusi dari kegiatan ini. 
b. Kegiatan pengabdian kepada masyarakat yang dilaksanakan ini mampu memberikan solusi sederhana untuk mengembangkan usaha mitra secara berkelanjutan dan memiliki daya saing.

c. Tercapainya target yang merupakan ukuran keberhasilan kegiatan pengabdian kepada masyarakat ini yaitu (1) peningkatan ketrampilan mitra dalam menjalankan usahanya dengan berkelanjutan, (2) administrasi sederhana yang tertib dan sehat, dalam arti mampu membuat pembukuan sederhana keuangan usahanya dan memisahkan keuangan rumah tangga dengan keuangan usaha, (3) peningkatan omzet penjualan dari kegiatan pemasaran yang efektif, (4) mendapatkan bantuan dana untuk tambahan modal usaha.

Kegiatan pengabdian kepada masyarakat ini dapat menghasilkan luaran sesuai dengan harapan mitra, yaitu (1) sumber daya manusia yang trampil dalam memasarkan produknya, dan (2) pengelolaan manajemen usaha dan administrasi keuangan yang benar dan teratur.

Tantangan terberat bagi mitra sebenarnya justru pada saat mereka benar-benar menghadapi persaingan usahanya ini. Oleh karena itu ada beberapa saran agar kegiatan ini dapat memberikan manfaat yang keberlanjutan, sebagai berikut:

a. Perlu adanya semangat dan kemauan yang tinggi bagi mitra untuk mengembangkan dirinya dengan membekali dirinya dengan peningkatan skill baik dalam kemampuan berinovasi maupun kemampuan manajemennya.

b. Tantangan persaingan yang cukup ketat harus diimbangi dengan mental dan sikap yang positif dan semangat yang tinggi pantang menyerah, karena jika mitra program tidak mempunyai jiwa kewirausahaan dan kemampuan berinovasi yang kuat maka akan mudah tergilas oleh tingkat persaingan usaha sejenis.

c. Pendampingan dan pengawasan yang intensif kepada mitra program perlu dilakukan secara periodik dan tidak berhenti sampai selesainya program ini, oleh karena itu keaktifan jajaran civitas STIE Widya Gama Lumajang dalam melakukan pembinaan pada kelompok usaha ini perlu dilakukan secara berkesinambungan.

d. Diharapkan pendanaan selanjutnya untuk kegiatan ini perlu dilaksanakan untuk membantu usaha kecil lainnya yang sejenis agar mampu berinovasi dan mampu berkembang dalam persaingan usaha yang semakin tajam. 